\title{
鋼板への電気Znめっき皮膜の結晶形態・配向性に及ぼす 硫酸塩めっき浴中に含有される微量無機添加物の影響
}

\author{
中野 博昭 $*$ ・荒賀 邦康 $*$ 岩井 正敏 $*$ 三木 賢二* \\ Effect of Trace Inorganic Additives on the Morphology and Crystal Orientation of Zn \\ Electrodeposited on the Steel from Sulfate Electrolyte \\ Hiroaki NaKano, Kuniyasu Araga, Masatoshi IwaI and Kenji MiKI
}

\begin{abstract}
Synopsis : The effects of trace inorganic additives on the morphology and crystal orientation of electrodeposited $\mathrm{Zn}$ have been investigated by using a polycrystal commercial low carbon Al-killed steel sheet as a base material and the sulfate bath with inorganic compounds of $4.8 \times 10^{-6} \sim 4.1 \times 10^{-2} \mathrm{~mol} / l$ to bath. The current density, flow rate and bath temperature are $50 \mathrm{~A} / \mathrm{dm}^{2}, 1.2 \mathrm{~m} / \mathrm{s}$ and $60^{\circ} \mathrm{C}$, respectively. The inorganic additives can be classified into 3 groups by the effects on the morphology and crystal orientation of electrodeposited $\mathrm{Zn}$. When the inorganic compounds of $\mathrm{Fe}, \mathrm{Ni}, \mathrm{Co}, \mathrm{Al}, \mathrm{Mg}$ and $\mathrm{Mn}$ (Group I) are added to the bath, the relative intensity of (0002) $\mathrm{Zn}$ and $\mathrm{Zn}$ crystal size do not change because Group I additives do not offend the heteroepitaxial growth of $\mathrm{Zn}$ and the overpotential for $\mathrm{Zn}$ deposition. When the inorganic componds of $\mathrm{Cr}, \mathrm{W}, \mathrm{Mo}$ and $\mathrm{Zr}$ (Group II) are added to the bath, the relative intensity of (0002)Zn increases because Group II additives do not change the heteroepitaxial growth of $\mathrm{Zn}$ but decreases the overpotential for $\mathrm{Zn}$ deposition. When the inorganic compounds of $\mathrm{Cu}, \mathrm{Pb}$, $\mathrm{Cd}, \mathrm{In}, \mathrm{Sn}, \mathrm{Ge}, \mathrm{Sb}$ and $\mathrm{Ag}$ (Group III) are added to the bath, the relative intensity of (0002) Zn increases and $\mathrm{Zn}$ crystal size becomes small because these additives co-deposit with $\mathrm{Zn}$ and prevent the heteroepitaxial growth of $\mathrm{Zn}$.
\end{abstract}

Key words: morphology of electrodeposited Zn; crystal orientation; overpotential; relative intensity; inorganic additive; Zn crystal.

\section{1. 緒言}

電気Znめっき皮膜の結晶形態は，電気Znめっき鋼板の 諸特性に影響を及ぼすことが知られている ${ }^{1-3) 。 そ の た め, ~}$ Znめっき皮膜の結晶形態制御に関する研究は, 電解条件, 浴条件について従来より多数行われている(1,4)。実機プロ セスでは，これまでに報告されてきた以外の重要な因子と して，めっき浴中への微量無機添加物の影響が考えられる。 Zn電析に及ぼす微量不純物共析については, これまでに, 微量元素の共析量実測值に関する報告 ${ }^{5,6)}, \mathrm{Zn}$ の結晶方位

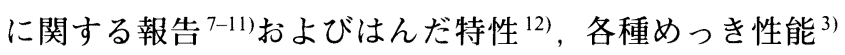
に関する報告がそれぞれ行われているが, 特に添加量が微 量な領域については, 不明な点が多く, また, 多種類の無 機添加物について，系統的に検討されている例はない。

そこで本報では，めっき浴中への各種無機添加物につい て, 微量領域で添加量を変化させ, $\mathrm{Zn}$ の結晶形態, 配向 性に及ぼす影響を調査し，その影響の度合いに応じて，無 機添加物を 3 種類にグループ分けした。また, 鋼板上に めっきされるZnのの配向性, 結晶サイズは, めっき過電圧 ${ }^{13)}$ および Zn/鋼板のエピタキシーの程度 $\left.{ }^{14}\right) に$ 依存することか ら, Znの析出電位抢よびZnのエピタキシャル成長に及ぼ す無機添加物の影響についても調査し, めっき過電圧, エ
ピタキシャル成長の両面から，無機添加物の影響を考察し た。

\section{2. 実験方法}

\section{$2 \cdot 1$ めっき条件}

めっき原板としては, 鉄多結晶体である低炭素 $\mathrm{Al}$ キル ド鋼材を使用した。なお，原板の結晶粒度は，JIS規格の フェライト粒度のNo.7である。電気Znめっきは, 白金陽 極板と鋼板を平行に立て，その間にめっき液を循環させる 循環式めっき装置を用いて, Table 1 に示す実用レベルの条 件にて行った。めっき浴は, 特級試薬とイオン交換水と により調整した。なお，無機添加元素は，アニオン種の 影響を除くため, 硫酸塩( $\mathrm{Fe}, \mathrm{Ni}, \mathrm{Co}, \mathrm{Cu}, \mathrm{Al}, \mathrm{Mg}, \mathrm{Mn}, \mathrm{In}$, $\mathrm{Ag}, \mathrm{Cd}, \mathrm{Sn}, \mathrm{Pb}, \mathrm{Zr})$, 酸化物 $(\mathrm{Cr}, \mathrm{Ge}, \mathrm{Sb}), \mathrm{Na}_{2} \mathrm{WO}_{4} \cdot 2 \mathrm{H}_{2} \mathrm{O}$, $\mathrm{Na}_{2} \mathrm{MoO}_{4} \cdot 2 \mathrm{H}_{2} \mathrm{O}$ の形で各々, $4.8 \times 10^{-6} \sim 4.1 \times 10^{-2} \mathrm{~mol} / l$ とな るよう基本浴に溶解した。めっき前処理としては, アルカ リ脱脂（オルソ珪酸ナトリウム, $60^{\circ} \mathrm{C}$, カソード電解 10 $\left.\mathrm{A} / \mathrm{dm}^{2} \times 30 \mathrm{~s}\right)$ および酸洗（10\%硫酸， $3 \mathrm{~s}$ 浸漬）を行った。

\section{$2 \cdot 2$ 無機添加物の共析量調查}

各種無機添加物を $1.0 \times 10^{-4} \mathrm{~mol} /$ と とるよう基本浴に溶 解後, Table 1に示す条件にてめっきを行った。無機添加物 
Table 1. Standard $\mathrm{Zn}$ plating conditions.

\begin{tabular}{l|l|l}
\hline $\begin{array}{l}\text { Bath composition } \\
(\mathrm{mol} / \mathrm{l})\end{array}$ & $\mathrm{ZnSO} \cdot 7 \mathrm{H}_{2} \mathrm{O}$ & 1.20 \\
& $\mathrm{Na} 2 \mathrm{SO} 4$ & 0.56 \\
& $\mathrm{H} 2 \mathrm{SO} 4$ & $0.31(\mathrm{pH}: 1.1)$ \\
\hline \multirow{5}{*}{ Operating conditions } & Current density $\left(\mathrm{A} / \mathrm{dm}^{2}\right)$ & 50 \\
& Flow rate $(\mathrm{m} / \mathrm{s})$ & 1.3 \\
& Temperature $\left({ }^{\circ} \mathrm{C}\right)$ & 60 \\
& Coating weight $\left(\mathrm{g} / \mathrm{m}^{2}\right)$ & 20 \\
& Cathode current efficiency $(\%)$ & 95 \\
& Anode-to-cathode gap $(\mathrm{mm})$ & 6 \\
& Cathode streamwise $(\mathrm{mm})$ & 100 \\
& Cathode height $(\mathrm{mm})$ & 50 \\
\hline
\end{tabular}

が Znめっき皮膜中に共析しているかどうかをX線マイク

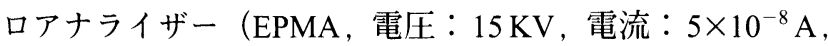
ビーム径 $20 \mu \mathrm{m})$ による点分析にて調査した。また，一部 の元素については，誘導結合高周波プラズマ分光分析 (ICP)を行った。

\section{$2 \cdot 3 \mathrm{Zn} /$ 鋼板のエピタキシー程度の評価と Zn 結晶サイ ズ・形態観察}

めっき後, $\mathrm{Zn}$ の結晶形態を走査型電子顕微鏡(SEM)にて 観察した。その SEM写真を基に，Zn 結晶が鋼板の結晶粒 毎に，一定の方向性をもって成長している部分の面積を画 像処理により測定し，全測定面積に占める割合を $\mathrm{Zn} /$ 鋼板 のエピタキシーの程度と定義した ${ }^{14)}$ 。多結晶 $\mathrm{Zn}$ 電析皮膜 の結晶粒同士の識別とその粒の大小の評価は, SEM 観察 に基づき，六角板状の積層体を呈する場合は，その積層体 が一つの結晶粒から成ると考えて, その辺や稜の長さを比 較し結晶サイズの大小を評価した。また，丸みを帯びた塊 状・柱状の突起群を呈する凹凸のある表面の場合は，その 塊状突起物を一つの結晶粒と識別し, その直径に相当する 長さを代表サイズとして考慮した。なお，Znの板状結晶 がクラスター毎に一方向に揃って積層しているのは，Zn が鋼板に対してエピタキシャル成長しているためであるこ

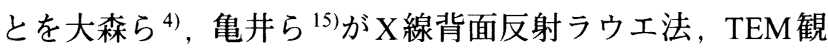
察により報告している。黒崎ら ${ }^{16)}$ は，SRX線回折法による その場連続観察により， $\mathrm{Zn}$ 電析が， $\mathrm{Fe}$ 基板の影響を受け るエピタキシー初期層（約 $3.5 \mathrm{~g} / \mathrm{m}^{2}$ 以下）と電解条件（過 電圧など）に支配されるその上のバルク電析層（約 3.5 $\mathrm{g} / \mathrm{m}^{2}$ 以上）とに区分されることを明らかにした。

\section{$2 \cdot 4 \mathrm{Zn}$ の結晶配向性調査}

$\mathrm{Zn}$ めっき皮膜結晶の(0002)面相対強度をX $\mathrm{X}$ 線回折装置 $(\mathrm{Cu}-\mathrm{K} \alpha$ ，管電圧 $40 \mathrm{kV}$ ，管電流 $20 \mathrm{~mA} ） に て$ 測定した。な お，(0002)Zn面相対強度 $[I F(0002)]$ は，(0002)Zn面から $(11 \overline{2} 2) \mathrm{Zn}$ 面までの全 $\mathrm{Zn}$ 面回折強度 $[\Sigma I(h k i l)]$ に対する (0002)Zn面の強度 $[I(0002)]$ の比として下記の(1)式より 算出した。

$$
I F(0002)=I(0002) / \Sigma I(h k i l)
$$

\section{$2 \cdot 5$ 陰極電位の測定}

各種無機添加物を $1.0 \times 10^{-4} \mathrm{~mol} / \mathrm{l}$ となるよう Table 1 に示

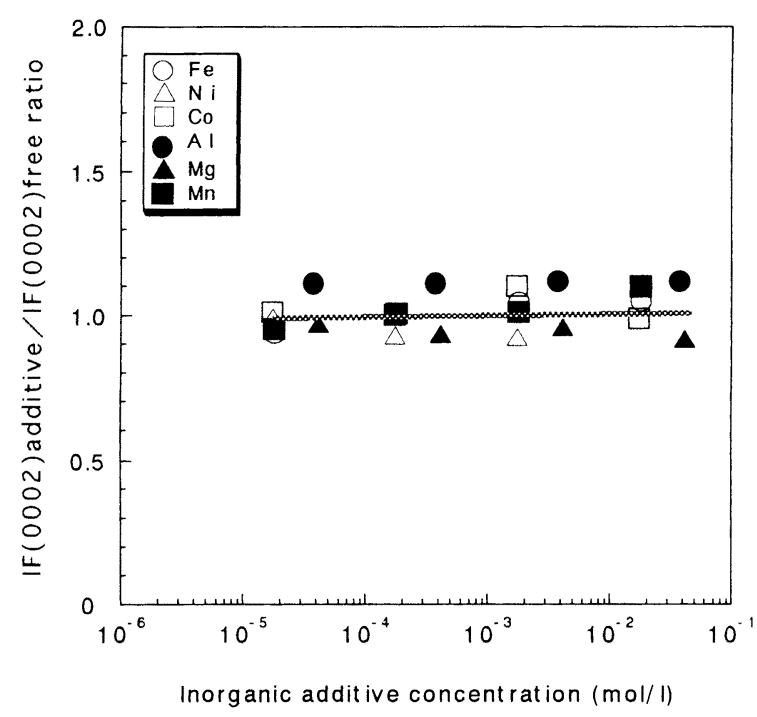

Fig. 1. Effect of inorganic additive on relative intensity of (0002) plane of electrodeposited $\mathrm{Zn}$.

す基本浴に溶解後, ビーカーめっき装置を用い, 電流密度 $10 \mathrm{~A} / \mathrm{dm}^{2}$, 浴温 $60^{\circ} \mathrm{C}$, 静止浴にてめっきを行い, めっき付 着量 $20 \mathrm{~g} / \mathrm{m}^{2}$ 時点での陰極電位を $\mathrm{Ag} / \mathrm{AgCl}$ 電極基準 $(0.197 \mathrm{~V}$ vs. NHE)で測定した。なお, 電流密度は，めっき液抵抗損 失の影響を避けるため, 標準条件 $\left(50 \mathrm{~A} / \mathrm{dm}^{2}\right)$ より低目とし, また測定電位は, 標準水素電極(NHE)基準の電位に換算し て表示した。物質移動の点で，ビーカーめっき装置の自然 対流と液循環式めっき装置の強制対流とでは，その物質移 動係数が数倍異なり，ビーカーめっきの場合には，微量無 機添加物の共析量が減少する可能性がある。また，陰極過 電圧の点では，液循環セルより小さいと推定できる。本論 分では, 微量添加物の共析量もその絶対值でなく, EPMA の相対強度比で相対評価しており，陰極電位の測定值もそ の相対值が判定できれば，良いものと考えた。

\section{3. 実験結果および考察}

\section{3・1 Zn 結晶の配向性に及ぼす微量無機添加物の影響}

電気 Znめっき鋼板の表面粗度 ${ }^{1)}$ ，プレス成形性 ${ }^{2)}$ ，クロ メ一ト反応性 ${ }^{3)}$ は，Zn六方稠密晶の基底面である(0002)面 の相対強度に依存することがこれまでに報告されている。 そこで，Znめっき皮膜結晶の代表的な面指数である(0002) 面の相対強度に及ぼす浴中への微量無機添加物の影響を調 査した。その結果を Fig. 1 3に示す。なお，困中縦軸の IF(0002)additiveは, 微量無機物添加浴での(0002)Zn面相対 強度を，またIF(0002)freeは，微量添加物なしの標準浴で の(0002)Zn面相対強度を表しており，IF(0002)additive/ $I F(0002)$ free 比が 1 を超えると，無機物添加により(0002)Zn 面相対強度が増加することを示している。なお，本研究で の IF(0002)free は 0.67 である。Fig. 1 に示す鉄族金属 $(\mathrm{Fe}, \mathrm{Ni}$, Co)または $\mathrm{Al}, \mathrm{Mg}, \mathrm{Mn}$ 添加浴では, 微量領域で添加量を変 


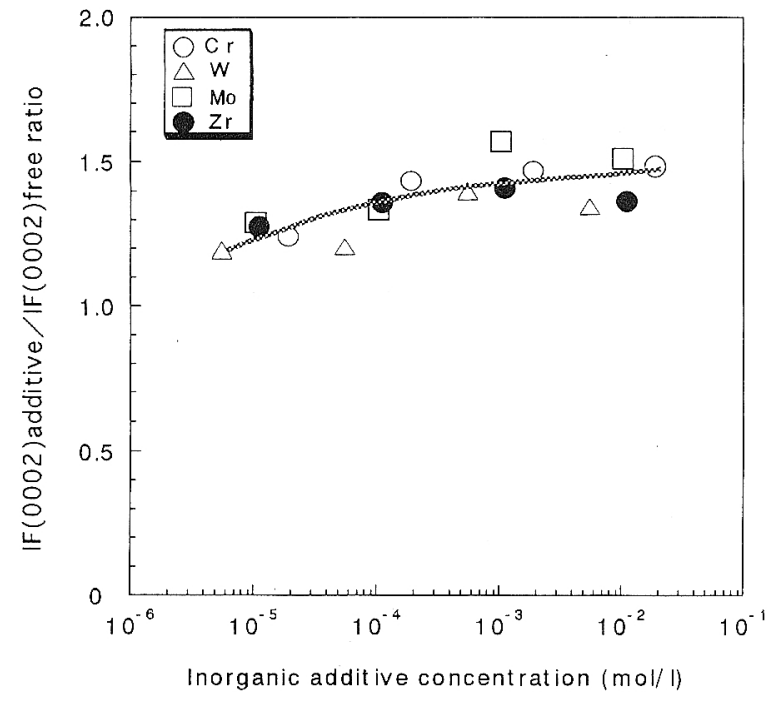

Fig. 2. Effect of inorganic additive on relative intensity of (0002) plane of electrodeposited $\mathrm{Zn}$.

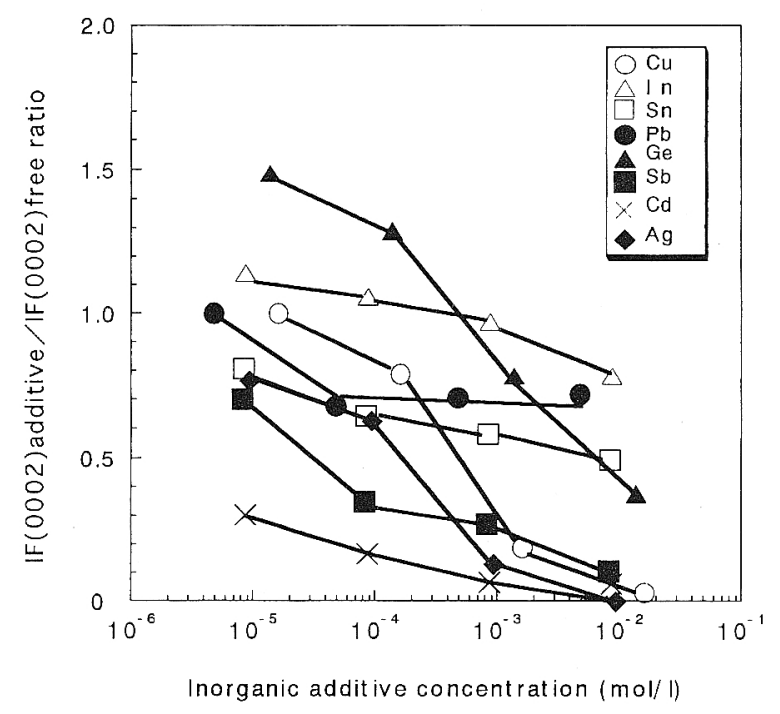

Fig. 3. Effect of inorganic additive on relative intensity of (0002) plane of electrodeposited $\mathrm{Zn}$.

化させても，(0002)Zn面の相対強度は，無添加の場合とほ ぼ同一で一定となっている。以下，この無機物のグループ をグループIと称する。

次に, Fig. 2 に示す Cr, W, Mo, Zr添加浴では, (0002)Zn 面の相対強度は, $10^{-5} \mathrm{~mol} / /$ 前後の添加量に打いても無添 加浴の場合より高くなっており，さらに添加量が増加する ほどより高くなる傾向にある。この4元素間での大きな差 は特に認められない。以下，この無機物のグループをグ ループIIと称する。

Fig. 3 には, Cu, In, Sn, Pb, Ge, Sb, Cd, Ag 添加浴の結果を 示す。これらの無機添加浴での特徵は, その添加量の増加 に伴い，(0002)Zn面の相対強度が低下していることであり， 一部を除き全体的に相対強度は，無添加浴の場合より低く なっている。ただし, 低下の程度, 相対強度の絶対値は,

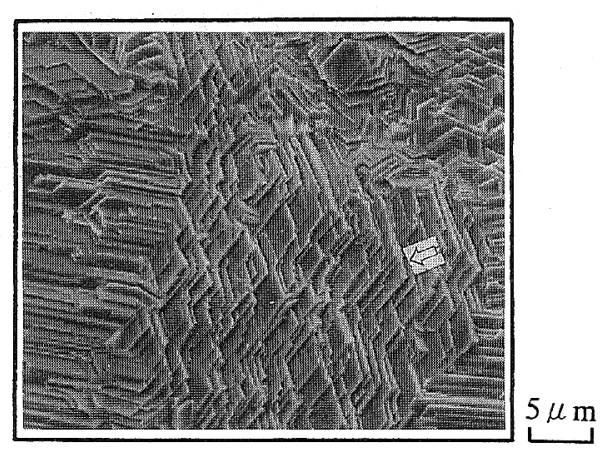

Fig. 4. Morphology of electrodeposited $\mathrm{Zn}$ without inorganic additive.

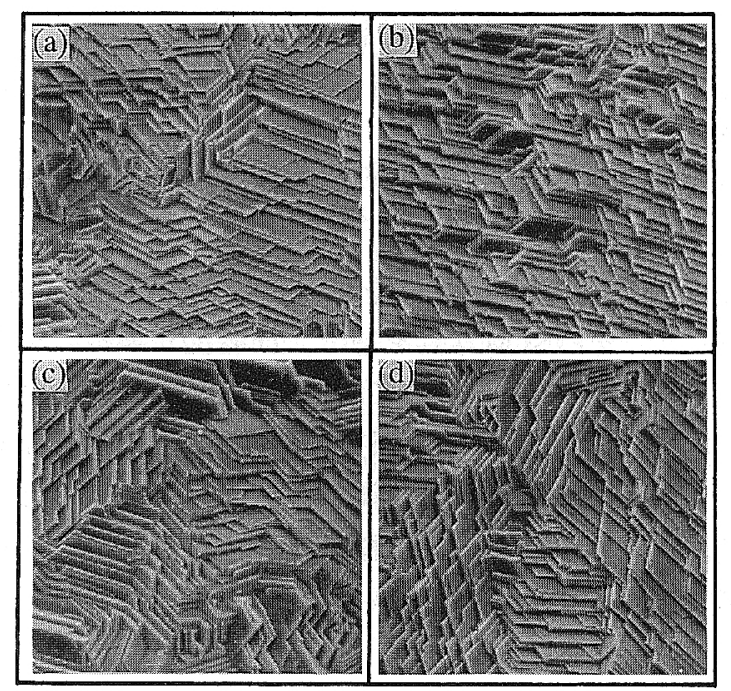

(a)Fe: $1.8 \times 10^{-5} \mathrm{~mol} / \mathrm{l} \quad$ (b)Fe: $1.8 \times 10^{-3} \mathrm{~mol} / \mathrm{l} 5 \mu \mathrm{m}$

$\begin{array}{ll}\text { (c) } \mathrm{Mn}: 1.8 \times 10^{-5} \mathrm{~mol} / 1 & \text { (d) } \mathrm{Mn}: 1.8 \times 10^{-3} \mathrm{~mol} / 1\end{array}$

Fig. 5. Effect of inorganic additive on the morphology of electrodeposited $\mathrm{Zn}$.

個々の元素により大きく異なっている。例えば, Ge添加 浴では，その添加量が $10^{-5} \sim 10^{-4} \mathrm{~mol} / /$ の範囲では， (0002)Zn面の相対強度は, 無添加の場合よりむしろ高く なっているが，それ以上の添加量範囲では，相対強度は急 激に低下している。なお，(0002)面以外の相対強度は，例 えば, $\mathrm{Cu}: 1.6 \times 10^{-3} \mathrm{~mol} / \mathrm{l}$ 添加浴では, (1011)面：0.29,

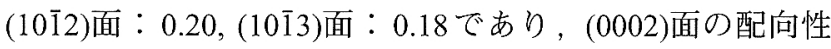
が弱くなっても，他の特定の面に変化するのではなく， 引 ンダム化していることがわかる。以下，この無機物のグ ループをグループIII と称する。

\section{3・2 Znの結晶形態に及ぼす微量無機添加物の影響}

Fig. 4 に微量添加物なしの標準浴での Zn 結晶形態を示 す。図中矢印で示すように，Zn結晶は，薄い板状結晶が 揃って積層し，大きく成長している。板状結晶が揃ってい るのは, 鋼板の結晶粒毎にZnがエピタキシャル成長して いるためである4)。なお，この薄い板状結晶の板面は，Zn 六方稠密晶の基底面(0002)Zn面である。

Fig. 5に，前項にて定義したグループIに属する Fe, Mn 


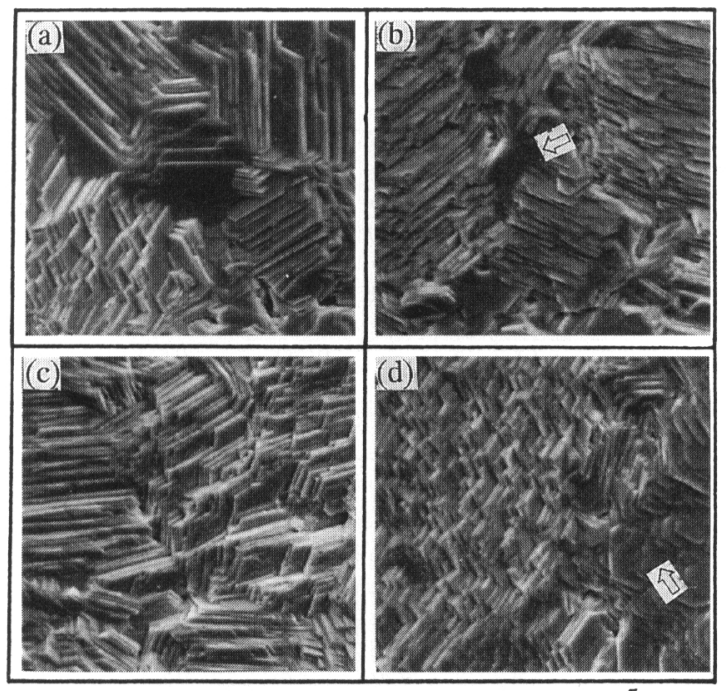

$\begin{array}{ll}\text { (a) } \mathrm{Cr}: 1.9 \times 10^{-5} \mathrm{~mol} / 1 & \text { (b) } \mathrm{Cr}: 1.9 \times 10^{-3} \mathrm{~mol} / 1 \quad 5 \mu \mathrm{m}\end{array}$ (c) Mo: $1.0 \times 10^{-5} \mathrm{~mol} / 1 \quad$ (d) Mo: $1.0 \times 10^{-3} \mathrm{~mol} / \mathrm{l}$

Fig. 6. Effect of inorganic additive on the morphology of electrodeposited Zn.

添加浴での Znの結晶形態を示す。いずれの添加浴, 添加 量においても，Znの結晶形態，結晶サイズは，Fig. 4 に示 す無添加浴の場合とほぼ同一であり，大きな板状結晶が一 定の方向に揃って積層している。グループIに属する Fe, Mn以外の無機物を添加した浴についても同様の結果が得 られた。すなわち, グループIに属する無機物は，Znの電 析結晶化過程に影響を及ぼさないと考えられる。

次に, グループIIに属する $\mathrm{Cr}, \mathrm{Mo}$ 添加浴からの $\mathrm{Zn}$ の結 晶形態を Fig. 6 に示す。両元素とも添加モル濃度が $10^{-5}$ オーダーと少ない場合は無添加浴の場合と同様に, Znの 板状結晶が一定の方向性を持って積層しており，Znは めっき最表面までエピタキシャル成長している。しかし， 添加濃度が $10^{-3} \mathrm{~mol} / \mathrm{l}$ オーダーになると, 板状結晶の シャープさがなくなりエッジがやや丸みを帯びたような形 状となる。また，積層方向も無添加浴に比べると僅かにラ ンダムになっている。さらに，Znの基底面 [(0002)Zn面] が鋼板と平行に析出し，表面が平滑化している（図中矢印 で示す）箇所が観察される。これは, 先の Fig. 2 でCr, Mo 添加浴では，(0002)Zn面の相対強度が高くなっていること と一致している。なお, グループIIの W, Zr添加浴につい ても Cr, Mo 添加浴と同様の結果が得られた。

次に Fig. 7に, グループIIIに属する $\mathrm{Cu}, \mathrm{Ge}$ 添加浴からの $\mathrm{Zn}$ 結晶形態を示す。 $\mathrm{Zn}$ の結晶形態は, $\mathrm{Cu}$ と $\mathrm{Ge}$ の添加浴 ではかなり異なっているが, 共通しているのは, 添加濃度 が $10^{-3} \mathrm{~mol} / l$ オーダーになると, Zn 板状結晶の一定方向に 揃った積層がほとんど認められなくなることである。すな わち, $\mathrm{Zn}$ のピタキシャル成長は, $\mathrm{Cu}, \mathrm{Ge}$ の添加量が多 くなると著しく阻害されることがわかる。また, Zn 結晶 のサイズは, $\mathrm{Cu}, \mathrm{Ge}$ の添加量が多くなると微細化している。

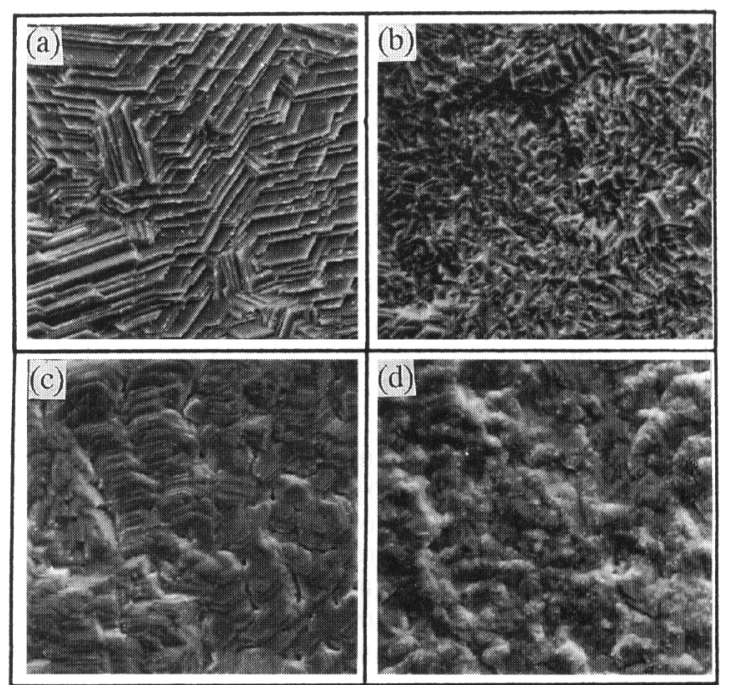

(a)Cu: $1.6 \times 10^{-5} \mathrm{~mol} / \mathrm{l} \quad$ (b) $\mathrm{Cu}: 1.6 \times 10^{-3} \mathrm{~mol} / \mathrm{l} \quad 5 \mu \mathrm{m}$ (c) Ge: $1.4 \times 10^{-5} \mathrm{~mol} / \mathrm{l} \quad$ (d) Ge: $1.4 \times 10^{-3} \mathrm{~mol} / \mathrm{l}$

Fig. 7. Effect of inorganic additive on the morphology of electrodeposited $\mathrm{Zn}$.

$\mathrm{Zn}$ 結晶粒微細化の原因としては, $\mathrm{Cu}, \mathrm{Ge}$ 添加による $\mathrm{Zn}$ の エピタキシャル成長抑制および $\mathrm{Cu}, \mathrm{Ge}$ 共析による $\mathrm{Zn}$ 核発 生密度の増加が考えられる。一方, 添加濃度が $10^{-5} \mathrm{~mol} / l$ オーダーと低い場合は, $\mathrm{Cu}$ 添加浴では, 無添加浴と同様 の形態になっているのに対して, $\mathrm{Ge}$ 添加浴からは, 丸み を帯びたサイズの小さいZnの板状結晶 [(0002)Zn面］が 鋼板とほぼ平行に積層している。この Ge添加浴での $\mathrm{Zn} の$ 結晶形態は, Fig. 3 において, Ge 添加濃度が $10^{-5} \mathrm{~mol} / l$ オーダーでは, (0002)Zn面の相対強度が, 無添加の場合よ り高くなっていることと対応している。グループIIIに属 するその他の無機添加浴からの Zn 結晶形態については, $\mathrm{In}, \mathrm{Pb}$ 添加浴では $\mathrm{Cu}$ 添加浴と類似の結晶形態を, $\mathrm{Sn}, \mathrm{Sb}$, $\mathrm{Cd}, \mathrm{Ag}$ 添加浴では $\mathrm{Ge}$ 添加浴と同様の結晶形態を示すこと がわかった。

\section{$3 \cdot 3$ 微量無機添加物の共析量調査}

各種微量無機添加浴からの Znめっき皮膜の結晶形態, 結晶配向性は，無機物の種類により大きく異なる。この一 因としては, 微量の無機添加物が $\mathrm{Zn}$ と共析するかどうか が関係していると考えられる。そこで，無機物のグループ 毎に，共析の有無をEPMAの点分析にて調査した。

Table 2 に, 微量無機物を添加していない浴と $10^{-4} \mathrm{~mol} / l$ 添加した浴でのめっき皮膜中の無機添加物と $\mathrm{Zn}$ の強度比 を示す。微量無機物を添加していない浴からの添加物の強 度比をブランク值として考え, 添加浴と無添加浴での強度 比を比較することにより無機添加物の共析の有無を判定し た。グループIの添加浴では，いずれも添加していない浴 との差がないことから, この添加濃度ではほとんど共析し ていないと考えられる。グループIIの添加浴についても， グループIの無機物同様, 無添加浴との差がないことから, 
Table 2. EPMA intensity ratio of additive to electrodeposited $\mathrm{Zn}$.

\begin{tabular}{|c|c|c|c|}
\hline \multicolumn{2}{|c|}{ Int. Ratio } & Without Additive & With Additive \\
\hline & $\mathrm{Fe} / \mathrm{Zn}$ & $7.65 \times 10^{-2}$ & $7.66 \times 10^{-2}$ \\
\hline \multirow{5}{*}{ I } & $\mathrm{Ni} / \mathrm{Zn}$ & $1.08 \times 10^{-2}$ & $1.08 \times 10^{-2}$ \\
\hline & $\mathrm{Co} / \mathrm{Zn}$ & $8.46 \times 10^{-3}$ & $8.45 \times 10^{-3}$ \\
\hline & $\mathrm{Al} / \mathrm{Zn}$ & $1.47 \times 10^{-1}$ & $1.45 \times 10^{-1}$ \\
\hline & $\mathrm{Mg} / \mathrm{Zn}$ & $7.49 \times 10^{-2}$ & $7.51 \times 10^{-2}$ \\
\hline & $\mathrm{Mn} / \mathrm{Zn}$ & $5.76 \times 10^{-3}$ & $5.75 \times 10^{-3}$ \\
\hline \multirow{4}{*}{ II } & $\mathrm{Cr} / \mathrm{Zn}$ & $4.85 \times 10^{-3}$ & $4.84 \times 10^{-3}$ \\
\hline & $\mathrm{W} / \mathrm{Zn}$ & $1.66 \times 10^{-2}$ & $1.64 \times 10^{-2}$ \\
\hline & $\mathrm{Mo} / \mathrm{Zn}$ & $3.43 \times 10^{-3}$ & $3.42 \times 10^{-3}$ \\
\hline & $\mathrm{Zr} / \mathrm{Zn}$ & $2.31 \times 10^{-3}$ & $2.31 \times 10^{-3}$ \\
\hline \multirow{8}{*}{ III } & $\mathrm{Cu} / \mathrm{Zn}$ & $1.38 \times 10^{-2}$ & $1.78 \times 10^{-2}$ \\
\hline & $\mathrm{In} / \mathrm{Zn}$ & $1.49 \times 10^{-2}$ & $1.55 \times 10^{-2}$ \\
\hline & $\mathrm{Sn} / \mathrm{Zn}$ & $1.62 \times 10^{-2}$ & $1.75 \times 10^{-2}$ \\
\hline & $\mathrm{Pb} / \mathrm{Zn}$ & $2.36 \times 10^{-2}$ & $2.51 \times 10^{-2}$ \\
\hline & $\mathrm{Ge} / \mathrm{Zn}$ & $2.07 \times 10^{-2}$ & $2.16 \times 10^{-2}$ \\
\hline & $\mathrm{Sb} / \mathrm{Zn}$ & $1.82 \times 10^{-2}$ & $1.93 \times 10^{-2}$ \\
\hline & $\mathrm{Cd} / \mathrm{Zn}$ & $1.10 \times 10^{-2}$ & $1.46 \times 10^{-2}$ \\
\hline & $\mathrm{Ag} / \mathrm{Zn}$ & $1.05 \times 10^{-2}$ & $1.28 \times 10^{-2}$ \\
\hline
\end{tabular}

ほとんど共析していないと思われる。一方，グループ III の添加浴からは，いずれも明らかに添加物の共析が認めら れる。ただし, 共析の程度は, 無添加浴と添加浴との差か ら判断すると, In, $\mathrm{Sn}, \mathrm{Ge}, \mathrm{Sb}, \mathrm{Pb}$ は少なく, $\mathrm{Cu}, \mathrm{Ag}, \mathrm{Cd}$ は, 多いと予想される。なお，グループ I と II の無機物につい ては, 添加濃度を $10^{-2} \mathrm{~mol} / l$ まで高くして ICP分析を行っ

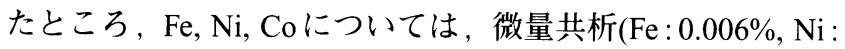
0.15\%, Co:0.01\%)していたが，それ以外はいずれも検出限 界 $\left(5 \times 10^{-3} \%\right)$ 以下であった。

ところで, $\mathrm{Zn}$ 電解においては, $\mathrm{Zn}$ はその水酸化物を経 由して電析を開始することが報告されている ${ }^{17)}$ 。福島ら は ${ }^{17)}$, 不純物を含有した電解採取浴からの Zn電析の臨界 電流密度の報告で, 不純物の挙動を検討するために化学お よび電気化学データを文献值 ${ }^{18,19)}$ を用いて計算している。

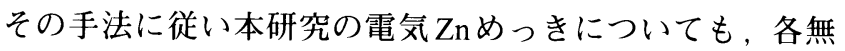
機添加物（濃度 $1 \times 10^{-4} \mathrm{~mol} / l$ ） が加水分解し始める $\mathrm{pH}_{\mathrm{cri}}$,

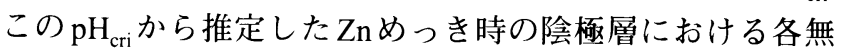
機添加物の形態, また, 各形態の化学種から金属電析が熱 力学的に可能となる平衡電位を求めた。その結果を Table 3 に示す。

グループIの鉄族金属 $(\mathrm{Fe}, \mathrm{Co}, \mathrm{Ni})$ は，その平衡電位が $\mathrm{Zn}$ の平衡電位より貴であるため熱力学的には金属状態で析出 できると考えられるが, 硫酸塩浴からの Zn-鉄族金属合金 電析は, 広い電解条件下で卑な Zn が優先析出する異常型 共析となることが報告されており ${ }^{20)}$, 本研究の微量添加浴 では, 共析量が非常に少ない。 $\mathrm{Al}, \mathrm{Mg}, \mathrm{Mn}$ は, その平衡電 位が $\mathrm{Zn}$ の平衡電位より卑であるため共析していないと考 えられる。

同様に，グループ II $\mathrm{Cr}, \mathrm{Zr}$ は，その平衡電位が $\mathrm{Zn}$ の平 衡電位より卑であるため共析していない。W, Moは，平衡 電位はZnの電位より貴であるが，不活性金属であり，鉄 族金属とは誘導型合金電析 ${ }^{20)} に よ り$ 析出するものの, $\mathrm{Zn}$
Table 3. Chemical and electrochemical data at the current density for $\mathrm{Zn}$ deposition.

\begin{tabular}{|c|c|c|c|c|c|}
\hline & $\mathbf{M}^{* 1)}$ & $n^{* 2)}$ & pHcri & Form & $\begin{array}{c}\mathrm{E}_{\mathrm{eq}} \\
\text { (v vs.NHE) }\end{array}$ \\
\hline & $\mathrm{Zn}$ & 2 & 5.44 & $\mathrm{Zn}(\mathrm{OH})_{2}$ & -0.761 \\
\hline \multirow{6}{*}{ I } & $\mathrm{Fe}$ & 2 & 8.65 & $\mathrm{Fe}^{2+}$ & -0.558 \\
\hline & $\mathrm{Ni}$ & 2 & 8.09 & $\mathrm{Ni}^{2+}$ & -0.368 \\
\hline & Co & 2 & 8.30 & $\mathrm{Co}^{2+}$ & -0.395 \\
\hline & $\mathrm{Al}$ & 3 & 4.55 & $\mathrm{Al}(\mathrm{OH})_{3}$ & -1.793 \\
\hline & $\mathrm{Mg}$ & 2 & 10.48 & $\mathrm{Mg}^{2+}$ & -2.481 \\
\hline & $\mathrm{Mn}$ & 2 & 9.66 & $\mathrm{Mn}^{2+}$ & -1.297 \\
\hline \multirow{4}{*}{ II } & $\mathrm{Cr}$ & 6 & - & $\mathrm{HCrO}_{4}$ & -0.833 \\
\hline & W & 6 & 5.03 & $\mathrm{WO}_{4}^{2-}$ & -0.419 \\
\hline & Mo & 6 & - & $\mathrm{MoO}_{4}^{2-}$ & -0.394 \\
\hline & $\mathrm{Zr}$ & 4 & 2.41 & $\mathrm{ZrO}_{2}$ & -1.874 \\
\hline \multirow{9}{*}{ III } & $\mathrm{Cu}$ & 2 & 6.61 & $\mathrm{Cu}^{2+}$ & 0.219 \\
\hline & In & 3 & 4.22 & $\mathrm{In}_{2} \mathrm{O}_{3}$ & -0.494 \\
\hline & Sn & 2 & 2.75 & $\mathrm{SnO}$ & -0.413 \\
\hline & $\mathrm{Pb}$ & 2 & 10.72 & $\mathrm{~Pb}^{2+}$ & $-0.356^{* 3)}$ \\
\hline & & & - & $\mathrm{PbSO}_{4}$ & -0.477 \\
\hline & $\mathrm{Ge}$ & 4 & - & $\mathrm{H}_{2} \mathrm{GeO}_{3}$ & -0.523 \\
\hline & $\mathrm{Sb}$ & 3 & 1.68 & $\mathrm{Sb}_{2} \mathrm{O}_{3}$ & -0.155 \\
\hline & $\mathrm{Cd}$ & 2 & 9.20 & $\mathrm{Cd}^{2+}$ & -0.521 \\
\hline & $\mathrm{Ag}$ & 1 & 15.95 & $\mathrm{Ag}^{+}$ & 0.563 \\
\hline \multicolumn{6}{|c|}{$\mathrm{M}^{* 1)} ;$ Additive metal $\left(10^{-4} \mathrm{~mol} / \mathrm{)}\right)$} \\
\hline$n^{* 2)}$ & \multicolumn{5}{|c|}{; Valency of additive metal } \\
\hline *3) & \multicolumn{5}{|c|}{$\begin{array}{l}\text {; Values for } \mathrm{Pb}^{2+} \text { which is in equilibrium with insoluble } \\
\mathrm{PbSO}_{4}\end{array}$} \\
\hline
\end{tabular}

とは共析しないと考えられる。

グループIIIの添加物は，いずれもその平衡電位が $\mathrm{Zn}$ の 平衡電位より貴であるため, 金属状態で共析していると考 えられる。

このように，グループI，IIの添加物は，Znと共析しな いか共析したとしてもその量が非常に微量であり，グルー プIIIの添加物のみ多量に共析しているが，これは，Fig. 5〜7について述べた $\mathrm{Zn}$ のエピタキシャル成長に及ぼす添 加物の影響と対応している。すなわち，グループI， IIの 添加物は共析しないか極微量の共析であるため, Znの工 ピタキシャル成長にも影響を及ぼさない。それに対して， グループIIIの添加物は，多量に共析することにより， Fig. 8 にも示すように一定の方向性を持った $\mathrm{Zn}$ 板状結晶の積層 を消失させている。すなわち, Znのエピタキシャル成長 を抑制している。このグループIIIの添加物共析によるエ ピタキシャル成長抑制の原因としては，以下の二点が考え られる。i）Znめっきは，(0002)基底面の沿面成長により形 成されることが Kosselにより報告されており ${ }^{21)}$ ，それによ ると $\mathrm{Zn}$ イオンが，Zn 結晶表面にアドイオンとして吸着し， アドイオンが $\mathrm{Zn}$ 結晶表面を拡散して, 単原子層厚さのス テップのキンクに組み込まれ成長する。しかし, 添加元素 が共析すると $\mathrm{Zn}$ 核発生速度が成長速度より相対的に速く なる可能性がある。その場合, 新たなめつき成長の起点と なる二次核生成速度が，アドイオンがキンクに組み込まれ る速度より速くなり，ランダム成長となり易い。ii) 添加 元素が成長しているZn 結晶のキンク，ステップ，テラス 等の特定サイトあるいは特定結晶面に析出することによ り，ランダム成長の起点となりやすい。

なお，Znと錯イオンを形成しやすいシアン化合物や小 


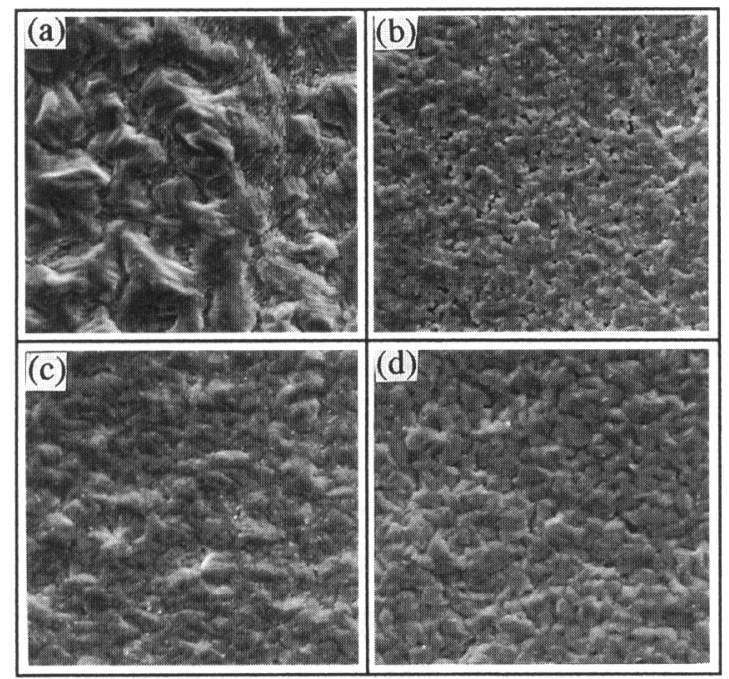

(a)Sn:0.8 $\times 10^{-3} \mathrm{~mol} / \mathrm{l} \quad$ (b)Sb: $0.8 \times 10^{-3} \mathrm{~mol} / \mathrm{l}$ $5 \mu \mathrm{m}$ (c) Cd: $0.9 \times 10^{-3} \mathrm{~mol} / \mathrm{l} \quad(\mathrm{d}) \mathrm{Ag}: 0.9 \times 10^{-3} \mathrm{~mol} / \mathrm{l}$

Fig. 8. Effect of inorganic additive on the morphology of electrodeposited Zn.

ロゲン化合物を含有しない硫酸塩化合物を主成分とする めっき浴からの Zn電析の場合, 陰極界面の $\mathrm{pH}$ は, pH1の 硫酸塩浴, $\mathrm{pH} 1$ 未満の電解採取浴からのZn電析において も Znの加水分解が生じる5.44に保持されていることが報 告されている22)。よって本研究での Zn 電析に打いても, Znめっき時には，除極界面の $\mathrm{pH}$ は，5.44に保持されてい ると仮定できる。そのため，加水分解し始める $\mathrm{pH}_{\mathrm{cri}}$ が 5.44 以下の無機添加物は加水分解して, 酸化物の形態で陰極層 に存在すると考えられる。例えば, Al, W, Zr, In, Sn, Sb は Table 3に示すような酸化物の形態になっていると予想され る。また, $\mathrm{Cr}, \mathrm{Mo}, \mathrm{Ge}$ は, 各々可溶性酸化物の形態であると 考えられる。

\subsection{Znの析出電位に及ぼす微量無機添加物の影響}

$\mathrm{Zn}$ の結晶形態, 配向性は, めっきの過電圧により変化 することがこれまでに報告されている131。そこで, 微量の 無機物添加により, めっき過電圧が変化するかどうかを調 査した。Table 4 に, 無機物を $10^{-4} \mathrm{~mol} / /$ となるように添加 した浴での Zn析出時の陰極電位を示す。なお，陰極電位 が貴側にシフトするほど，めっき過電圧は小さくなってい ると言える。グループ「の添加浴では, 除極電位は無添加 浴とほぼ一致して扔り，めっき過電圧は変化していない。 それに対して, グループIIの添加浴では, いずれも陰極電 位は約 $10 \mathrm{mV}$ 貴側にシフトしておりめっき過電圧が小さく なっている。また, グループIIIの添加浴では, 無機物の 種類により傾向が異なり, めっき過電压は, $\mathrm{Cu}, \mathrm{Pb}, \mathrm{Cd}$ 添 加浴では無添加浴と同等, In, Sn, Ge, Sb, Ag 添加浴では約 10〜20 mv低下している。

次に, グループIIの添加物について, 添加濃度と陰極電 位の関係を Fig. 9に示す。いずれの添加物についても, 程 度に差はあるものの添加量が増加するほど陰極電位は貴側
Table 4. Effect of inorganic additive on the cathode potential.

\begin{tabular}{|c|c|c|}
\hline \multicolumn{2}{|r|}{ Additive } & $\begin{array}{l}\text { Cathode potential } \\
\text { (V vs. NHE) }\end{array}$ \\
\hline \multicolumn{2}{|r|}{ Free } & -0.782 \\
\hline \multirow{6}{*}{1} & $\mathrm{Fc}$ & -0.778 \\
\hline & $\mathrm{Ni}$ & -0.782 \\
\hline & Co & -0.781 \\
\hline & $\mathrm{Al}$ & -0.783 \\
\hline & $\mathrm{Mg}$ & -0.780 \\
\hline & $\mathrm{Mn}$ & -0.779 \\
\hline \multirow{4}{*}{ II } & $\mathrm{Cr}$ & -0.773 \\
\hline & W & -0.768 \\
\hline & Mo & -0.772 \\
\hline & $\mathrm{Zr}$ & -0.772 \\
\hline \multirow{8}{*}{ III } & $\mathrm{Cu}$ & -0.779 \\
\hline & In & -0.764 \\
\hline & Sn & -0.762 \\
\hline & $\mathrm{Pb}$ & -0.783 \\
\hline & $\mathrm{Ge}$ & -0.761 \\
\hline & $\mathrm{Sb}$ & -0.761 \\
\hline & $\mathrm{Cd}$ & -0.785 \\
\hline & $\mathrm{Ag}$ & -0.773 \\
\hline
\end{tabular}

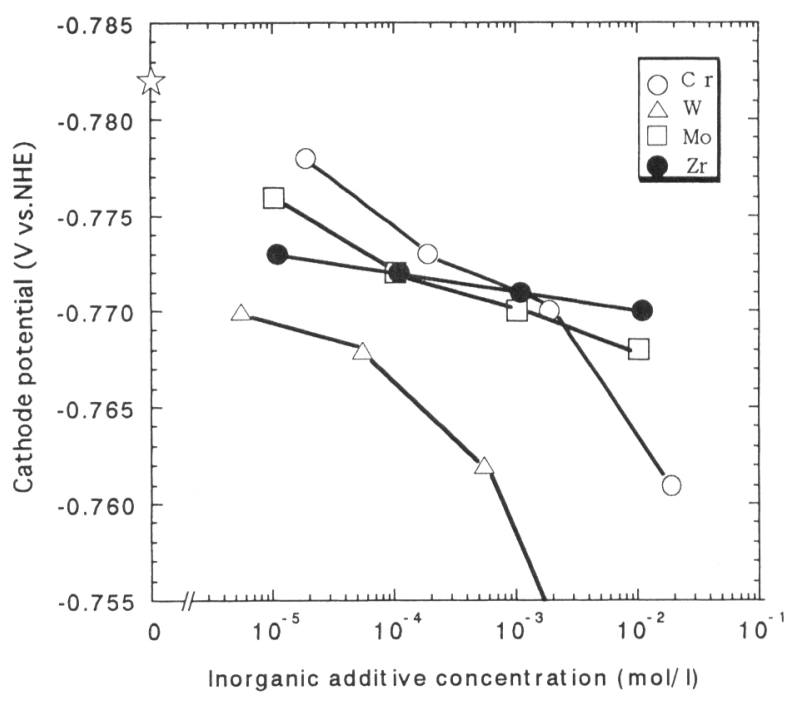

Fig. 9. Effect of inorganic additive on cathode potential of electrodeposition.

にシフトしており，めっき過電压を低下させる作用を有し ていることがわかる。

このように, グループ II の $\mathrm{Cr}, \mathrm{W}, \mathrm{Mo}, \mathrm{Zr}$ 打よびグループ IIIの In, Sn, Ge, Sb, Ag添加浴において, めっき過電圧の減 少が認められる。この原因としては，以下の二点が考えら れる。i)これらの元素に共通しているのは, Table 3からわ かるように, Ag以外はZnめっき時に, 㓌極界面では酸化 物の状態で存在していると予想されることである。 $\mathrm{MoO}_{4}{ }^{2-}, \mathrm{ReO}_{4}{ }^{-}$などのO-化合物は，水素析出に対して，触 媒作用を有することが知られている ${ }^{23)}$ 。除極界面に形成さ れるグループII, IIIの酸化物も酸素を含有した O-化合物 であり, 水素の析出を促進させると推察される。これらの 元素を添加した本実験に扔いて, めっき電流効率は, 無添 加の場合に比較して 4 16\%の低下がみられた。水素の析 出が促進されることにより, 除極反応 Totalの分極曲線が 
Table 5. Summary of effect of inorganic additive on $(0002) \mathrm{Zn}$ relative intensity and crystal size of electrodeposited $\mathrm{Zn}$.

\begin{tabular}{|c|c|c|c|c|c|c|}
\hline & Additive & $\begin{array}{l}\text { Codeposition } \\
\left.\text { of additive }{ }^{* 1}\right)\end{array}$ & $\begin{array}{l}\text { Zn/Steel } \\
\text { epitaxy }\end{array}$ & $\begin{array}{l}\text { Overpotential } \\
\text { of deposit }\end{array}$ & $\begin{array}{l}(0002) \mathrm{Zn} \\
\text { relative } \\
\text { intensity }\end{array}$ & $\begin{array}{l}\text { Crystal size } \\
\text { of } \mathrm{Zn}\end{array}$ \\
\hline \multirow{2}{*}{ I } & $\begin{array}{l}\mathrm{Fe}, \mathrm{Ni} \\
\mathrm{Co}\end{array}$ & 1 & \multirow{2}{*}{ No Change } & \multirow{2}{*}{ No Change } & \multirow{2}{*}{ No Change } & \multirow{2}{*}{ No Change } \\
\hline & $\begin{array}{l}\mathrm{Al}, \mathrm{Mg} \\
\mathrm{Mn}\end{array}$ & 0 & & & & \\
\hline II & $\begin{array}{l}\mathrm{Cr}, \mathrm{W} \\
\mathrm{Mo}, \mathrm{Zr}\end{array}$ & 0 & No Change & Decrease & Increase & No Change \\
\hline \multirow{4}{*}{ III } & $\mathrm{Cu}, \mathrm{Cd}$ & 3 & \multirow{4}{*}{ Decrease } & No Change & \multirow{4}{*}{ Decrease } & \multirow{4}{*}{ Decrease } \\
\hline & $\mathrm{Pb}$ & 2 & & & & \\
\hline & $\mathrm{Ag}$ & 3 & & \multirow[b]{2}{*}{ Decrease } & & \\
\hline & $\begin{array}{l}\text { In,Sn } \\
\mathrm{Ge}, \mathrm{Sb}\end{array}$ & 2 & & & & \\
\hline
\end{tabular}

貴側にシフトし，結果的にめっき過電圧が低下すると考え られる。なお，Agについては，Znに比べ水素過電圧が低 いことが知られている24)。このため， Zn 皮膜中に共析し た $\mathrm{Ag}$ は，水素析出を促進し，酸化物と同様の作用により， めっき過電圧を減少させると考えられる。ii)これらの元 素のイオンまたは析出原子が成長している $\mathrm{Zn}$ 結晶の特定 サイトに吸着することにより Zn 自体の析出過電圧を低下 させる。

\section{3·5 Zn 結晶の配向性, サイズとめっき過電圧, エ ピタキシャル成長の関係}

Pangarov ${ }^{13)}$ は, 種々の結晶面上での 2 次元核形成仕事の 相対值の計算を行い，与えられた結晶化過電圧で核形成の 仕事の最も小さい面を持つ2次元核が生成するとして，優 先配向の過電圧依存性を示している。それによると, Zn めっきの場合, 過電圧が高くなると基底面である(0002)Zn の相対強度が低下する。実際，電気Znめっきにおいて， 過電圧が高くなると, $(0002) \mathrm{Zn}$ 面の相対強度が低くなるこ とが報告されている ${ }^{1)}$ 。また，一方では，電析する $\eta$ $\mathrm{Zn}(\mathrm{hcp})$ は， $\alpha$ - Fe(bcc)基板上ではバーガースの方位関係 $[(110) \alpha / /(0001) \eta]$ に従いエピタキシャル成長することが知 られている ${ }^{4,15)}$ 。本研究では, 使用した鋼板の(110)Fe面の $\mathrm{X}$ 線相対強度は 0.61 と高くなっているため, Znがエピタ キシャル成長している際は，(0002)Zn面に優先配向すると 考えられる。実際著者らは市販の鋼板への電気 Znめっき において, めっき過電压が高くなると $\mathrm{Zn}$ の結晶サイズが 小さくなり，Zn/鋼板のエピタキシーが低下すると (0002)Zn面の相対強度, 結晶サイズが減少することを報告 している ${ }^{14)}$ 。

そこで, Zn 結晶の配向性, サイズに及ぼす微量無機添 加物の影響を, めっき過電圧, Zn/鋼板のエピタキシーの 観点から Table 5 に整理した。グループIの鉄族金属 $(\mathrm{Fe}, \mathrm{Ni}$,

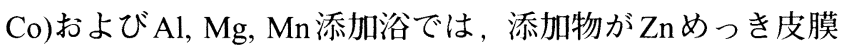

中には共析しないか共析したとしても極微量であるため, $\mathrm{Zn} /$ 鋼板のエピタキシーが変化しない。また，めつき過電 圧も無添加浴とほぼ同一である。したがって，グループI の無機物は微量添加しても，(0002)Zn面の相対強度, 結晶 サイズとも変化させない。

一方, グループIIの Cr, W, Mo, Zr 添加浴では, 添加濃度 が $10^{-3} \mathrm{~mol} / \mathrm{l}$ オーダー以上になると, $\mathrm{Zn}$ 板状結晶の積層方 向が僅かにランダムになっているものの，グループIの添 加浴同様, 添加物が $\mathrm{Zn}$ わき皮膜中に共析しないため, 基本的には $\mathrm{Zn} /$ 鋼板のエピタキシーはほとんど変化しない と考えられる。また，グループIIの添加浴では，めっき過 電圧が低下している。このように，Zn/鋼板のエピタキ シ一を変化させず, めっき過電圧のみを低下させるため, (0002)Zn面の相対強度は増加する。Zn結晶のサイズは, めっき過電圧が低下していることから大きくなると予想さ れたが，過電圧低下による影響が小さすぎるためか，ほと んど変化していない。

次に，グループIIIの添加浴では，いずれの添加物とも Znめっき皮膜中に明らかに共析するため, 添加量が増加 するほど $\mathrm{Zn} /$ 鋼板のエピタキシーは低下する。一方，めつ き過電圧は, 添加物の種類により異なり, $\mathrm{Cu}, \mathrm{Pb}, \mathrm{Cd}$ 添加 では変化がなく, In, Sn, Ge, Sb, Ag添加では減少する。 (0002)Zn面の相対強度は, $\mathrm{Zn}$ 鋼板のエピタキシ一低下の 影響を強く受け，めっき過電圧が低下している In, Sn, Ge, $\mathrm{Sb}, \mathrm{Ag}$ 添加浴でも減少している。ただし, $\mathrm{Ge}, \mathrm{In}$ 添加浴で はFig. 3 に示したように，添加量が少ない領域では，無添 加浴の場合より(0002)Zn面の相対強度は高くなっている。 これは, 添加量が少ない領域では, $\mathrm{Zn} /$ 鋼板のエピタキ シ一の低下が少なく，エピタキシー低下の影響よりもめつ き過電圧低下の影響をより強く受けたためと考えられる。 なお，グループIIIの添加浴での Zn 結晶サイズは小さくな る。この原因としては, 添加物の共析による $\mathrm{Zn}$ エピタキ シャル成長の抑制および $\mathrm{Zn}$ 析出核発生密度の増加が考え られる。このため, めっき過電圧を下げる添加浴において も，Zn結晶サイズは全体的に小さくなる傾向がある。

\section{4. 結言}

電気 Znめっき皮膜の結晶形態，配向性に及ぼす浴中へ の微量無機添加物の影響を調査した結果，以下の知見が得 られた。

無機添加物は, Znめっき皮膜の結晶形態，配向性に及 ぼす影響の度合いに応じて以下の3種類に分類できる。

グループIの鉄族金属 $(\mathrm{Fe}, \mathrm{Ni}, \mathrm{Co})$ ならびに $\mathrm{Al}, \mathrm{Mg}, \mathrm{Mn}$ は， めっき皮膜中に共析しないか共析したとしても極微量であ るため，Znのエピタキシャル成長打よびめっき過電圧に 影響を及ぼさないため，(0002)Zn面の相対強度，Zn結晶 サイズとも変化させない。 
グループ II の Cr, W, Mo, Zr は，めっき皮膜中に共析しな いため，Znのエピタキシャル成長には影響を及ぼさない。 ただし，めっき時に陰極層では，酸化物の形態で存在し ていると予想され，めっき過電压を低下させるため， (0002)Zn面の相対強度を増加させる。なお， Zn 結晶サイ ズはほとんど変化させない。

グループ III の Cu, Pb, Cd, In, Sn, Ge, Sb, Ag は, Znめっき 皮膜中に共析し，Znのエピタキシャル成長を抑制するた め, (0002)Zn面の相対強度を低下させ, Zn 結晶サイズを 小さくする傾向がある。

本研究を行うにあたり，有益なご助言をいただきました 九州大学大学院工学研究科教授福島久哲博士に厚く御礼申 し上げます。

\section{文献}

1 ) M.Sagiyama, M.Kawabe and T.Watanabe: Tetsu-to-Hagané, 76 (1990), 1301

2 ) S.J.Shaffer, W.E.Nojima, P.N.Skarpelos and J.W.Morris, Jr.: ZinkBased Steel Cating Systems, Metallurgy and Performance, Pennsylvania, (1990), 251.

3 ) A.Yakawa, M.Kimoto and T.Tsuda: CAMP-ISIJ, 2 (1989), 615

4 ) H.Ohtsubo, T.Matsumoto, K.Nakai and Y.Ohmori: ISIJ Int., 34 (1994), 1002.

5 ) L.F.G.Williams: J.Electrochem.Soc., 126 (1979), 566.

6 ) M.Maja, N.Penazzi, R.Fratesi and G.Roventi: J. Electrochem. Soc., 129 (1982), 2695.

7 ) R.Sato: J.Electrochem. Soc., 106 (1959), 206.
8 ) D.J.Mackinnon and J.M.Brannen: J. Appl. Electrochem., 7 (1977), 451.

9 ) D.J.Mackinnon, J.M.Brannen and R.C.Kerby: J. Appl. Electrochem., 9 (1979), 55.

10) P.A.Adcock, A.R.Ault and O.M.G.Newman: J. Appl. Electrochem., 15 (1985), 865

11) Y.B.Yim, W.S.Hwang and S.K.Hwang: J. Electrochem. Soc., 142 (1995), 2604.

12) K.Koike, J.Fujimoto, K.Yazaki and K.Kanda: J. Surf. Finish. Soc. Jpn., 45 (1994), 1047

13) N.A.Pangarov: Electrochim. Acta, 9 (1964), 721.

14) H.Nakano, K.Araga, M.Iwai and J.Kawafuku: Tetsu-to-Hagané, 83 (1997), 785.

15) K.Kamei and Y.Ohmori: Int. Conf. on Zinc and Zinc Alloy Coated Steel Sheet (GALVATEC'89), ISIJ, Tokyo, (1989), 449.

16) M.Kurosaki, M.Imafuku and K.Kawasaki : 4th Int. Conf. on Zinc and Zinc Alloy Coated Steel Sheet (GALVATEC'98), ISIJ, Tokyo, (1998), 521.

17) H.Fukushima, T.Akiyama and T.Ohgai: Shigen-to-Sozai, 110 (1994), 967.

18） A.J.Bard 著, 松田好晴, 小倉興太郎訳: 溶液内イオン平衡, 化 学同人, 東京, (1975), 194.

19) M.Pourbaix: Atlas of Electrochemical Equilibria, Pergamon Press, Oxford, (1966).

20) T.Akiyama, H.Fukushima and K.Higashi: Tetsu-to-Hagané, 72 (1986), 918.

21) J.Bockris and G.A.Razumney: Fundamental Aspects of Electrocrystallization, Plenum Press, New York, (1967), Chapter 1, 2.

22) H.Fukushima: 4th Int. Conf. on Zinc and Zinc Alloy Coated Steel Sheet (GALVATEC'98), ISIJ, Tokyo, (1998), 497.

23) H.Fukushima, T.Akiyama, Y.Toyoshima and K.Higashi: J. Met. Finish. Soc. Jpn., 36 (1985), 198

24) 田村英雄, 松田好晴: 現代電気化学, 培風館, 東京, (1977), 163. 